to be 'real men,' by not fulfilling the 'masculine' breadwinner role. She suggests that this explains the considerable over-representation of domestic violence in lowincome families in the US statistics, and contends that domestic violence could be prevented by eliminating male unemployment and employment discrimination against black men. But this thesis contradicts evidence she puts forward in other parts of the book and is not borne out by the vast amount of survey research on domestic violence in the US as well as in many other countries (see for example Davies, 1994; Gelles, 1997). This is not to deny that some men's domestic violence may be exacerbated by unemployment but to recognize that is not a sufficient explanation in itself.

Another problematic area is represented in her explanation of the causes of poverty and her focus on individualistic solutions. In Raphael's view, poverty is largely seen as a problem of 'social exclusion' and 'welfare dependency' and there appears to be little recognition of any structural causes. The solution is therefore to enable mothers to get off welfare, even though this may be into low-paid work, where their income can be even lower than state benefits. Despite this, she argues that women on welfare who experience domestic violence need to work, because this overcomes their isolation and develops a sense of autonomy, self-worth and achievement. While this may be true for some women, it is not necessarily a solution to the collective problems of gendered poverty and women's low pay, which are related far more to the needs of global capitalism.

In some ways I feel that Raphael tries to do too much with her material in this book and to make too many connections, between the three areas of domestic violence, welfare policy and poverty. Nevertheless she highlights some important issues that are relevant to the 'welfare to work' approaches for 'lone' mothers in the UK, including the need to screen and provide protection for women from domestic violence in these kinds of public policy measures.

Lynne Harne

doi:10.1057/palgrave.fr. 9400094

\title{
In our time: memoir of a revolution
}

Susan Brownmiller; Aurum Press Ltd, London, 2000, £12.99 Pbk ISBN 1-85410-700-3, 368pp

In Our Time brings alive the late 1960s and 1970s feminist activism within the United States. It is a historical and, at some stages, autobiographical story of the women's second wave revolution. The book is more about the action than about the complex theory that was developed during this period. As is well known, Susan Brownmiller played an important role in this movement. She participated in some 
of the radical activist organizations and consciousness raising groups such as the New York Radical Feminists and The Red Stockings. Her most famous contribution to the movement was as a feminist author. Brownmiller's book Against Our Will (1975) was a groundbreaking analysis of rape. Her theories transformed the understanding of rape from a practice that an individual woman was responsible for, to a crime that men performed on women as a form of, and maintenance of, power. From the position of a feminist author and activist within the American second wave movement, Brownmiller is well placed to tell the story of the radical transformations made.

The book places into over all context the writing of second wave feminist texts such as The Feminine Mystique (Friedan, 1963), The Dialectic of Sex (Firestone, 1970), Sexual Politics (Millet, 1970), The Myth of the Vaginal Orgasm (Koedt, 1973) Against Our Will (Brownmiller, 1975) and The Hite Report (Hite, 1976). In Our Time describes how the women's movement influenced the writing of these texts and the influence that these texts had on the movement. The book does not give commentary or analysis on the theories of these texts and would serve more as a complement or an introduction to American second wave feminist theory.

In Our Time describes how the women's movement was about more than a set of academic texts. Second wave feminism, we are told, was about large scale collective action and demonstration, women being angry and standing up to patriarchy at every level of society: from the bedrooms, the law courts and working environments to the government. In Our Time recounts the rise and fall of multiple women's organizations, beginning with liberal feminism and Friedan's founding of the National Organization for Women (NOW) in 1966 (that focused upon equal opportunities in employment and pay) and contrasting with the later more radical feminist movements known collectively as Women's Liberation in which Brownmiller herself performed a key role. Brownmiller spends more time describing the later organizations that were formed as non-hierarchical, decentralized, counter culture units based upon analysis, theory and radical activism. She recounts how she was converted to feminist action through such a unit at a New York Radical Feminist consciousness raising session. At this group meeting Brownmiller, as well as many others in the room, recounted their experiences of their life endangering illegal abortions performed in the back streets of Puerto Rico and Cuba. She describes the meeting as providing the necessary momentum for Susan Brownmiller to commit herself to the feminist cause.

The book maps out the development of key feminist issues that arose out of such consciousness raising meetings: the personal is political; how to discuss sex and sexuality; women's right to abortion; new ways to understand rape; the acknowledgement and naming of the battery of women, sexual abuse of children and sexual harassment; and finally the divisive understandings of pornography as crime against women. In Our Time describes how these concepts were developed and negotiated through consciousness raising groups, workshops, 
speak outs and conferences. Brownmiller then outlines how these notions were used to change the many masculine-dominated cultures in the United States law and society. This was mainly achieved through direct action that took many forms: sit-ins, marches, protests, art, guerrilla theatre, civil disobedience, truth squads, all women dances, disseminating information through newsletters and leaflets, lobbying, learning how to administer abortions and challenging laws in the courts. Many of their direct actions are discussed in detail throughout the text, beginning with the Miss America protests and recounting stories such as the Ladies Home Journal sit-in, Women's strike for equality and the pornography tours in Times Square.

In Our Time also reflects upon the negative aspect of the radical feminists groups, namely the bitter internal fighting. The leftist ideals of no hierarchy or leaders are described as problematic because the feminists who gained personal fame through the movement and were seen to be spokespeople, were often battered down and exiled. Brownmiller recounts how she and many other women were 'trashed' for being the 'stars' and the 'elitists' (Brownmiller, 2000: 60) of the movement. Brownmiller writes with quite a bitter tone on these issues often feeling the need to justify certain actions and statements that she used at the time.

In Our Time is written in such a way that you feel engulfed within the movement. It is written as a piece of journalistic text, containing many interview extracts from feminists of this period. These interviews were performed recently by Brownmiller for the purpose of writing In Our Time. The feeling of being absorbed into the movement is evoked through the juxtaposing of these extracts with vivid imagery of the people and the locations. The imagery with the multiple voices helps the reader to feel part of the text and gives it a cinematic quality. This makes reading the book compulsive as you experience the protests, the marches and the sit-ins making radical statements and non-negotiable demands.

The charge that second wave feminism was a basically white, middle class and heterosexual affair is not so clear cut in Brownmiller's account of the movement. In Our Time refers throughout to episodes of negotiation, disagreements and co-operation between black and hispanic, lesbian and working class women within the women's liberation movement, and describes how all types of women contributed to the changes made during this period. This is made apparent from the start of the women's liberation movement which was born from women who worked in the civil rights movements and demonstrations in the United States. For example, the book discusses Mary King and Casey Hayden's early second wave paper $A$ Kind Of Memo that was written within the

1 SNCC was a civil rights organizsation formed in 1960 that who performed tasks such as registering Student Non-violent Co-ordinating Committee (SNCC). ${ }^{1}$ This paper discussed the idea that women were second class to white men and examined the correlations with the position of blacks in America. The paper became a source for women's discussion and developed into women's groups despite resentment 
and belittling from the men within this SNCC. Frances Beal, a black feminist from the SNCC was also cited for her written contribution Double Jeopardy: to be black and female and the rise of the National Black Feminist Organization that began in 1973.

The problem that Brownmiller's book does not approach is that women with different experiences were never given the centre space and academic opportunity to make richer the key feminist texts of this period. What has struck feminist academics about second wave feminism was the prominence of the organization and written texts of the white, heterosexual, middle class and educated of the time, and that these authors never really mentioned in their texts how their experiences differed and connected to women who were other (Barkley Brown, 1995). An example of the lack of understanding of difference was that white, middle class women during the late 1970s were beginning to succeed in equal pay and careers because of black or working class women performing the domestic or poorly paid work which white, middle class, women were no longer expected to do (Barkley Brown, 1995).

Despite the recurrent theme of lack of acknowledgement of difference that haunts second wave feminism, this book has much to offer young women. As a young feminist this book had a profound effect upon me: the realization that the life of women today that I considered to be 'normal' has only been created within the last 30 years. Although I do not consider there is equality for women today the transformations that have been achieved are dramatic and largely through radical second wave feminists both in the UK and in the United States. However, perhaps I can only speak as a middle class, educated, white, woman in the UK. In Our Time emphasises what little action we take now to maintain and better women's position in our society. black voters in the South of the United States.

\section{Bryony Hoskins}

\section{references}

Barkley Brown, $\boldsymbol{\varepsilon}$. (1995) 'What has happened here' in D.C. Hine, W. King and L. Reed (1995) editors, We Specialize in the Wholly Impossible: A reader in Black Women's History (Black Women in United States History, Vol. 17), New York: Carlson Press.

Beal, F. (1970) 'Double jeopardy: to be black and female' in R. Morgan (1970) editor, Sisterhood is Powerful, New York: Random house.

Brownmiller, S. (1975) Against Our will: Men Women and Rape, New York: Simon and Schuster.

Firestone, S. (1970) The dialectic of sex, New York: William Morrow.

Friedan, B. (1963) The Feminine Mystique, New York: Norton.

Hite, S. (1976) The Hite Report, New York: Dell Publishing Co. 
King, M. and Hayden, C. (1966) 'A kind of memo,' In C. Hayden and M. King (1966) editors, To a Number of Other Women in the Peace Movement, reprinted in M.E. King (1987), Freedom Song: A Personal Story of the 1960's Civil Rights Movement. New York: William Morrow.

Koedt, A. (1973) 'Myth of the vaginal orgasm', notes from the first year: expanded version in: Koedt, Levine and Rapone (1973) editors, Radical Feminism, New York: Quadrangle.

Millet, K. (1970) Sexual Politics, New York: Doubleday.

doi: $10.1057 /$ palgrave.fr. 9400095

\section{Feminism, the state and social policy}

Nickie Charles, Macmillan Press, Basingstoke, 2000, Pbk, ISBN 0-333-65556-7, f17.99256pp

\section{'Race', gender, social welfare: encounters in a postcolonial society}

Gail Lewis, Polity Press, Cambridge, 2000, Hbk, ISBN 0-7456-2284-4 f55.00, Pbk, ISBN 0-7456-2285-2 £15.99 248pp

Well-rehearsed debates in feminist theory and epistemology between modern, structural approaches to understanding gender inequalities and the poststructural disruption of the category 'woman' are increasingly being played out in the arena of social policy. In social policy, unlike many other disciplines, a strata of academics, researchers, politicians and policymakers are actively and intimately bound up with the workings of the state. From a pluralist perspective, the policy world is a competitive forum, where different interest groups vie for position. The role of social policy actors is to shape the policy agenda in their particular interests and their task is to network, build alliances and enter the arena of the opposition or government policy development process. This is a 'real' world, where power is vital, palpable, visible and deeply embedded in aspects of the social policy psyche.

In the last few years, post-structural approaches have challenged this scenario, destabilizing the theoretical frameworks and processes of policy development, offering a critical alternative to understanding the discourse and effects of social policy agendas. The stumbling block is that they seem to undermine and constrain the possibility of action and social change, which are the driving imperatives of policy development. These two books reflect the tensions between the two approaches. Nickie Charles charts the influence of second wave feminism on social policy. Gail Lewis shifts the focus to the involvement of welfare institutions and practices in the constitution and government of new welfare subjects.

At the centre of Nickie Charles' analysis is the paradox, which continues to frame and to thwart feminist politics. As she suggests, it arises from the practical reality that the capacity of feminist social movements to influence policy agendas is in the gift of a resistant state that supports and maintains the social relations that 